DOI: $10.19195 / 0137-1134.112 .3$

\title{
JAROSŁAW FIRLIT
}

Uniwersytet Wrocławski

\section{PRZEDSIĘBIORSTWO W POLSKIM SYSTEMIE PRAWNYM}

Abstrakt: Prezentowane opracowanie stanowi przedstawienie problematyki pojęcia przedsiębiorstwa w polskim systemie prawnym. Jego celem jest zaprezentowanie złożoności definicji przedsiębiorstwa w świetle obowiązujących przepisów prawnych, orzecznictwa sądowego i dogmatyki prawnej.

Z uwagi na charakter artykułu główną metodę badawczą stanowi obiektywna analiza porządku prawnego, regulującego kwestie przedsiębiorstwa mającego na celu usystematyzowanie najistotniejszych zagadnień w prezentowanym temacie.

Słowa kluczowe: przedsiębiorstwo, system prawny, działalność gospodarcza, składniki przedsiębiorstwa

\section{WPROWADZENIE}

Artykuł $55^{1}$ k.c. zawiera definicję legalną przedsiębiorstwa. Samo określenie ,przedsiębiorstwo" ma wiele znaczeń, a ustalenie in concreto definicji to skomplikowana problematyka. Termin „przedsiębiorstwo” może być używany w ustawodawstwie zasadniczo w trzech znaczeniach, a mianowicie podmiotowym, funkcjonalnym i przedmiotowym. W znaczeniu podmiotowym odnosi się do przedsiębiorcy i jest używany w kontekście ustawy o przedsiębiorstwach państwowych. Jednakże czasami w tej konwencji językowej posługujemy się terminem ,przedsiębiorstwo” w tłumaczeniach tekstów prawa Unii Europejskiej, czego najlepszym przykładem są reguły konkurencji w Traktacie o funkcjonowaniu Unii Europejskiej ${ }^{1}$. Są one adresowane do przedsiębiorstw w znaczeniu podmiotów działających na jednolitym rynku Unii Europejskiej. Drugi aspekt omawianego terminu to znaczenie funkcjonalne — odnosi się ono do pewnego zakresu działalności gospodarczej prowadzonej przez przedsiębiorcę. Tak zastosowany znajdujemy ów termin np. w art. $22 \S 1$ k.s.h. Trzeci wariant jest znaczeniem przedmiotowym ${ }^{2}$, a jego adekwatną sferą rozważań są te regulacje kodeksu spółek handlowych,

1 Zob. art. 101 i 102 Traktatu o funkcjonowaniu Unii Europejskiej Dz. Urz. UE 2016 C 202.

2 W.J. Katner, [w:] Prawo cywilne - część ogólna, System Prawa Prywatnego, t. 1, wyd. 1, red. M. Safjan, Warszawa 2007, s. 1223. 
w których występuje zwrot „prowadzenie przedsiębiorstwa”. Pojawia się on nie tylko w definicjach poszczególnych spółek osobowych ${ }^{3}$, lecz także w przepisach ogólnych dotyczących tych spółek. Chodzi tu mianowicie o art. $8 \S 2$ k.s.h. przepis ten stanowi, że spółka osobowa prowadzi przedsiębiorstwo pod własną firmą. Zgodnie z regułą jedności prawa cywilnego, wyrażoną de lege lata dobitnie w art. 2 k.s.h., kodeks spółek handlowych stanowi lex specialis w stosunku do kodeksu cywilnego jako lex generalis ${ }^{4}$. Aby można było ustalić znaczenie wyrażenia „prowadzi przedsiębiorstwo" w odniesiesieniu do przepisów kodeksu spółek handlowych, należy odnieść się do regulacji zawartych w kodeksie cywilnym, w którym $\mathrm{w}$ wielu unormowaniach występuje to określenie, jak też zwrot „w zakresie swego przedsiębiorstwa”. Verbi causa należy wskazać na art. $109^{1} \S 1$, art. $358^{1}$ $\S 4$, art. 554, art. $583 \S 1$, art. 751 pkt 1 k.c. — w jurysprudencji jest prezentowane stanowisko, że w wymienionych formułach przedsiębiorstwo jest rozumiane w znaczeniu, jakie nadaje mu art. $55^{1}$ k.c. Analizie należy poddać także przepisy definiujące umowy nazwane, zwłaszcza te o świadczenie usług kwalifikowane ze względu na status usługodawcy, np. art. $758 \S 1$, art. 765, art. 774, art. $794 \S 1$ k.c. Jest w nich mowa o zobowiązaniu w zakresie działalności przedsiębiorstwa ${ }^{5}$. W znaczeniu podmiotowym pojęcie przedsiębiorstwa bywa używane do oznaczenia podmiotu, który prowadzi działalność gospodarczą. Identyfikuje ono wówczas podmiot, dzięki któremu przedsiębiorstwo w znaczeniu przedmiotowym uczestniczy w obrocie gospodarczym i prawnym. Najczęściej wskazywanym przykładem takiego zastosowania omawianego pojęcia jest przedsiębiorstwo państwowe. Pojęcie podmiotowe przedsiębiorstwa bywa obecnie utożsamiane z przedsiębiorcąa ${ }^{6}$.

\section{SKŁADNIKI PRZEDSIĘBIORSTWA}

Przedsiębiorstwo może składać się z więcej niż jednego przedsiębiorstwa w znaczeniu przedmiotowym. Tak rozumianym przedsiębiorstwem może być także gospodarstwo rolne. Innymi słowy, gospodarstwo rolne może stanowić jedno z przedsiębiorstw spółki, a w konsekwencji może być przedmiotem obrotu jako całość 7 . Do tego aspektu przedsiębiorstwa nawiązują, modyfikując go w zależności od potrzeb, regulacje pozakodeksowe ${ }^{8}$. Natomiast zgodnie z przepisami art. 2

3 Zob. art. $22 \S 1$, art. $86 \S 1$, art. 102 i art. 125 k.s.h.

4 M. Pazdan, Kodeks spółek handlowych a kodeks cywilny, „Państwo i Prawo” 2001, nr 2, s. $28-36$.

5 J.P. Naworski, Przedsiębiorca i przedsiębiorstwo w polskim prawie prywatnym. Cz. I, „Przegląd Prawa Handlowego" 2015, nr 8, s. 4-12.

6 W. Katner, op. cit., Nb 135.

7 Postanowienie Sądu Najwyższego — Izba Cywilna z dnia 9 grudnia 2010 r., sygn. akt IV CSK 210/10, publikacja Legalis nr 414631.

8 J.P. Naworski, op. cit. 
ust. 1 pkt 8 i pkt 9 ustawy o działalności leczniczej ${ }^{9}$. Stanowią, że przedsiębiorstwo jest zespołem składników majątkowych, za pomocą którego podmiot leczniczy wykonuje określony rodzaj działalności leczniczej. W tym znaczeniu szpital jest przedsiębiorstwem podmiotu leczniczego — podmiot ten wykonuje działalność leczniczą w rodzaju świadczeń szpitalnych ${ }^{10}$. Prima facie do przedsiębiorstwa $\mathrm{z}$ art. $55^{1}$ k.c. nawiązuje art. 97 k.c., w którym jest mowa o osobie czynnej w lokalu przedsiębiorstwa. Nie ma uzasadnionych podstaw opinia, że chodzi w nim o przedsiębiorcę prowadzącego przedsiębiorstwo, którego składnikiem jest ten lokal ${ }^{11}$. Lokal przedsiębiorstwa, w świetle tego przepisu, to w istocie miejsce prowadzenia przez przedsiębiorcę działalności gospodarczej, niezależnie od tego, czy stanowi element przedsiębiorstwa w ujęciu przedmiotowym. Łatwo wyobrazić sobie przedsiębiorcę, który sprzedaje artykuły spożywcze w niewielkim sklepiku osiedlowym czy używaną odzież w baraku, które nie stanowią przedsiębiorstwa ani nie wchodzą w jego skład. Mimo to nie ma wątpliwości, że do osoby czynnej w takim lokalu należy stosować art. 97 k.c. Poprawność przedstawionej wykładni potwierdzają argumenty systemowe nawiązujące do definicji lokalu przedsiębiorstwa, zawartej w art. 2 pkt 3 ustawy o prawach konsumenta. Zgodnie z tym przepisem jest to miejsce prowadzenia działalności, będące nieruchomością albo częścią nieruchomości, w którym przedsiębiorca prowadzi działalność na stałe, lub miejsce prowadzenia działalności będące rzeczą ruchomą, w którym przedsiębiorca prowadzi działalność zwyczajowo albo na stałe ${ }^{12}$.

\section{ZNACZENIE FUNKCJONALNE PRZEDSIĘBIORSTWA}

Określenie przedsiębiorstwa w znaczeniu funkcjonalnym stanowić będzie jedynie określenie konkretnej działalności gospodarczej, jaka jest prowadzona zgodnie z kategorią określoną w Polskiej Klasyfikacji Działalności.

W doktrynie dyskusję wzbudził przykład ,przedsiębiorstwa, które mieści się w teczce i laptopie" (a ściślej dwóch teczkach i dwóch laptopach wspólników spółki cywilnej, jeżeli zawierają one potrzebne do działalności informacje, np. listę kontaktów biznesowych). Należy zgodzić się w poglądem, że ocena, czy doszło do zbycia przedsiębiorstwa, powinna być dokonywana in concreto ${ }^{13}$. Przyjmuje się, że do uznania zorganizowanego zespołu składników niematerial-

9 Ustawa z 15 kwietnia 2011 r. o działalności leczniczej, tekst jedn. Dz.U. z 2015 r., poz. 618 ze zm.

10 J.P. Naworski, op. cit.

11 M. Pazdan, [w:] Kodeks cywilny. Komentarz, t. 1, red. K. Pietrzykowski, Warszawa 2004, s. 340 .

12 J.P. Naworski, op. cit.

13 S. Buczkowski, Glosa do wyroku Sądu Najwyższego z 10 stycznia 1972 r., OSPiKA 1972, nr 12, s. 232. 
nych i materialnych za przedsiębiorstwo nie jest konieczne, by w danej chwili za pomocą tego zespołu rzeczywiście prowadzona była działalność produkcyjna, handlowa, usługowa itd. Wystarcza bowiem, by zespół ten był zdolny do prowadzenia działalności tego rodzaju, a przedsiębiorstwo nie traci w związku z tym swojego charakteru. Dotyczy to czasowego zawieszenia prowadzenia działalności gospodarczej (np. sezonowość), o ile przedsiębiorstwo pozostaje w dalszym ciągu zorganizowane, a w celu podjęcia i prowadzenia dalszej działalności gospodarczej nie zachodzi konieczność dodatkowych przygotowań do jej rozpoczęcia ${ }^{14}$. Taka wykładnia doprowadziła ad casu do uznania, że przedsiębiorstwem nadal pozostaje nieczynny pensjonat nieprowadzący żadnej działalności hotelarsko-gastronomicznej i w związku z tym niezatrudniający personelu do obsługi gości hotelowych ${ }^{15}$. Niewątpliwie należy mieć na uwadze kwestie formuły prowadzenia przedsiębiorstwa i zakresu działalności przedsiębiorstwa zarówno w doktrynie, jak i judykaturze.

\section{ZNACZENIE PRZEDMIOTOWE PRZEDSIĘBIORSTWA}

Wkrótce po wejściu w życie kodeksu spółek handlowych stało się oczywiste, że pojawią się wątpliwości, czy w wymienionych unormowaniach chodzi o przedmiotowe, czy o funkcjonalne pojęcie przedsiębiorstwa ${ }^{16}$. J. Szwaja uważa, iż cel w postaci prowadzenia przedsiębiorstwa mieści się w pojęciu „,eel gospodarczy”, o którym mowa w art. $860 \S 1$ k.c. Jednocześnie twierdzi, że obecnie spółki, podobnie jak pod rządami kodeksu handlowego, mogą być zawiązywane w celach gospodarczych. Jeżeli jednak cel ten jest realizowany przez prowadzenie przedsiębiorstwa, to spółka taka powinna przybrać postać osobowej spółki handlowej ${ }^{17}$. Szwaja broni także stanowiska, że termin ,przedsiębiorstwo” występuje w art. 8 $\S 2$, art. $22 \S 1$ i art. 102 k.s.h. w znaczeniu przedmiotowym. Za takim stwierdzeniem przemawia przede wszystkim rezygnacja z formuły wykonywania działalności gospodarczej mającej konotację funkcjonalną i użytej w regulacjach działalności gospodarczej. Kolejną wskazówką uzasadniającą przedmiotowe rozumienie pojęcia „przedsiębiorstwo" ma być jego zdefiniowanie w art. $55^{1}$ k.c. Przyjmując za podstawę art. 2 k.s.h., należy pojęciom, których sam kodeks spółek handlowych nie określa, nadać znaczenie przypisywane im w kodeksie cywilnym. W tym kie-

14 Z. Gawlik, [w:] Kodeks cywilny. Komentarz, t. 1, Część ogólna, red. A. Kidyba, Warszawa 2009, s. 275.

15 P. Bielski, Glosa do wyroku Sądu Najwyższego z 17 października 2000 r., I CKN 850/98, PPH 2004, nr 3, s. 46.

16 J. Szwaja, Nowy kodeks spółek handlowych. Cz. 1, „Prawo Spółek” 2001, nr 1, s. 7.

17 Ibidem. 
runku wypowiadała się już doktryna przedwojenna ${ }^{18}$. To samo stanowisko, aczkolwiek bez szerszego uzasadnienia, przedstawia J.A. Strzępka i E. Zielińska ${ }^{19}$. S. Sołtysiński natomiast nie precyzuje jednoznacznie stanowiska w tym temacie. W świetle art. $22 \S 1$ k.s.h. twierdzi najpierw, że przez prowadzenie przedsiębiorstwa należy rozumieć prowadzenie we własnym imieniu, zarobkowo lub w innym celu oraz w sposób zorganizowany i ciągły działalności gospodarczej. Terminu „przedsiębiorstwo" nie powinno się utożsamiać z pojęciem przedsiębiorstwa w rozumieniu art. $55^{1}$ k.c. Następnie autor ów stwierdza, że rozpoczęcie działalności przez spółkę prowadzi do powstania przedsiębiorstwa $\mathrm{w}$ znaczeniu przedmiotowym, mimo że jego rozmiary mogą być skromne. Zorganizowane i funkcjonujące przedsiębiorstwo posiada majątek w szerokim tego słowa znaczeniu (aktywa i pasywa), firmę, księgi handlowe i klientelę ${ }^{20}$. P. Bielski uważa, że przepisy dotyczące spółki partnerskiej, zawarte w art. $86 \S 1$ k.s.h., definiujące prowadzenie przedsiębiorstwa, określają je w ujęciu przedmiotowym ${ }^{21}$. Autor ów stawia tezę, iż uznanie spółki partnerskiej za spółkę handlową przeznaczoną, jak pozostałe osobowe spółki handlowe, do prowadzenia przedsiębiorstwa wywołuje stanowczy sprzeciw. Ignoruje istnienie fundamentalnych różnic między dwiema postaciami działalności gospodarczej: prowadzeniem przedsiębiorstwa i wykonywaniem wolnego zawodu. Oznacza to w konsekwencji regulację oczywiście sprzeczną z wymogami spójnego systemu prawa i obowiązującymi w nim zasadami techniki prawodawczej22. Charakterystyczną, a przy tym konstytutywną cechą wykonywania wolnego zawodu jest natomiast wyłącznie osobiste dokonywanie przez osobę fizyczną wszystkich czynności związanych bezpośrednio z prowadzoną działalnością gospodarczą. Wymienione różnice między tymi postaciami działalności gospodarczej muszą istnieć też w przypadku wspólnego prowadzenia przedsiębiorstwa czy też wspólnego wykonywania wolnego zawodu ${ }^{23}$. W ocenie Bielskiego natomiast prowadzi to w naturalny sposób do konkluzji, że spółka zawiązana w celu wspólnego wykonywania wolnego zawodu (np. spółka partnerska) z przyczyn obiektywnych w żadnym razie nie może być uznana za spółkę prowadzącą przedsiębiorstwo we wspólnym imieniu $^{24}$. Bielski wskazuje w związku z tym, że wielość elementów stanowi podstawowy warunek uznania spółki za przedsiębiorstwo w rozumieniu art. $55^{1}$ k.c. Jest to przy tym warunek konieczny, ale niewystarczający.

18 J. Szwaja, I.B. Mika, [w:] Kodeks spótek handlowych, t. 1, Przepisy ogólne. Spótki osobowe. Komentarz do art. 1-150, red. S. Sołtysiński et al., Warszawa 2012, s. 815-816; J. Szwaja, [w:] Kodeks spótek handlowych. Komentarz, t. 5, red. S. Sołtysiński, A. Szajkowski, A. Szumański, Warszawa 2004, s. 481.

19 J.A. Strzępka, E. Zielińska, [w:] Kodeks spótek handlowych. Komentarz, red. J.A. Strzępka, Warszawa 2009, s. 17.

20 S. Sołtysiński, [w:] Kodeks spółek handlowych, t. 1, Przepisy ogólne..., s. 382.

21 P. Bielski, Spótka partnerska — spótka handlową?, „Prawo Spółek” 2006, nr 2, s. 12-19.

22 P. Bielski, Spółka partnerska..., s. 12.

23 J.P. Naworski, op. cit.

24 P. Bielski, Spótka partnerska..., s. 12-19. 
Drugą zasadniczą cechą charakteryzującą przedsiębiorstwo jest element organizacji jego składników ${ }^{25}$. M. Pazdan wskazuje regulacje art. $109^{1} \S 1$ in fine k.c. stanowiącym, że prokura obejmuje umocowanie do czynności sądowych i pozasądowych, jakie są związane z prowadzeniem przedsiębiorstwa. Chodzi o przedsiębiorstwo należące do mocodawcy. Jego zbycie, oddanie w dzierżawę czy użytkowanie powoduje wygaśnięcie prokury ${ }^{26}$. Natomiast T. Wiśniewski analizuje unormowanie art. $358^{1} \S 4$ k.c., który wyłącza prawo żądania waloryzacji sądowej strony prowadzącej przedsiębiorstwo, jeżeli świadczenie pozostaje w związku z prowadzeniem tego przedsiębiorstwa. Uznaje, że użyte w nim pojęcie „przedsiębiorstwo" musi być rozumiane w znaczeniu przedmiotowym ${ }^{27}$. Także M. Sychowicz broni tezy, że skoro pojęcie przedsiębiorstwa zostało zdefiniowane $\mathrm{w}$ art. $55^{1}$ k.c., to obecnie też na tle art. 751 pkt 1 k.c., stanowiącego o osobach, które w zakresie działalności przedsiębiorstwa trudnią się czynnościami danego rodzaju, pojęcie to musi być tak jednolicie rozumiane ${ }^{28}$. Niewątpliwie należy tu poświęcić uwagę stanowisku P. Bielskiego, który jest zwolennikiem przedmiotowego ujęcia przedsiębiorstwa $\mathrm{w}$ analizowanych formułach ${ }^{29}$. Poza prowadzeniem działalności gospodarczej, jak zatrudnienie, wolny zawód czy samodzielne wykonywanie rzemiosła, polegającej wyłącznie na osobistym dokonywaniu wszystkich czynności związanych bezpośrednio z tą działalnością, autor ten wyróżnia prowadzenie przedsiębiorstwa. Ten rodzaj działalności gospodarczej wymaga poważnych środków finansowych, istotnego stopnia organizacji składników niematerialnych i materialnych służących do jej prowadzenia, zatrudnienia pracowników mających kwalifikacje dostosowane do rodzaju prowadzonej działalności. Specyficzną odmianę prowadzenia przedsiębiorstwa stanowi prowadzenie gospodarstwa rolnego, różniące się od prowadzenia przedsiębiorstwa jedynie przedmiotem (rodzajem) działalności gospodarczej — rolnictwem ${ }^{30}$.

Konsekwencją przedstawionego wywodu jest stwierdzenie P. Bielskiego, że w razie użycia w systemie prawa, scilicet $\mathrm{w}$ kodeksie cywilnym, wyrażenia „działalność gospodarcza” w określonym kontekście chodzi — z zastrzeżeniem wyjątków - o taką działalność w każdej postaci ${ }^{31}$. Jeżeli natomiast termin „przedsiębiorstwo" występuje w określonym kontekście, np. prowadzącego przed-

25 P. Bielski, Glosa do wyroku Sądu Najwyższego z 17 października 2000 r. ..., s. 46.

${ }^{26}$ M. Pazdan, [w:] System prawa prywatnego, t. 2, Prawo cywilne-czesść ogólna. Suplement, red. Z. Radwański, Warszawa 2004, s. 90 i 102-103.

27 T. Wiśniewski, [w:] Komentarz do kodeksu cywilnego. Księga trzecia. Zobowiąania, t. 1, red. G. Bieniek, Warszawa 1996, s. 45.

28 M. Sychowicz, [w:] Komentarz do kodeksu cywilnego. Ksiega trzecia. Zobowiazania, t. 2, red. G. Bieniek, Warszawa 1997, s. 259.

29 P. Bielski, Glosa do wyroku Sadu Najwyższego z 14 stycznia 2004 r., sygn. akt I CK 54/03, „Prawo Spółek” 2007, nr 5, s. 54-59.

30 P. Bielski, Cele definiowania gospodarstwa rolnego w systemie prawa - uwagi z perspektywy prawa handlowego, „Rejent” 2005, nr 9, s. 70.

31 J.P. Naworski, op. cit. 
siębiorstwo, w zakresie działalności przedsiębiorstwa ${ }^{32}$, to wymienione zwroty należy rozumieć wyłącznie jako prowadzenie działalności gospodarczej w formie przedsiębiorstwa $\mathrm{w}$ znaczeniu przedmiotowym ${ }^{33}$. Ponieważ jednak w obecnym stanie prawnym przedsiębiorcą jest prowadzący działalność gospodarczą w każdej postaci, to, zdaniem P. Bieckiego, używanie w jednym przypadku formuły „prowadzący działalność gospodarczą”, w innym zaś „,prowadzenie przedsiębiorstwa” nie znajduje racjonalnego uzasadnienia ${ }^{34}$.

\section{PRZEDSIĘBIORSTWO W ORZECZNICTWIE}

Na szczególne uznanie zasługuje opisanie wypowiedzi judykatury dotyczących wykładni prowadzenia przedsiębiorstwa. Pierwsze judykaty dotyczyły waloryzacji sądowej, którą wyłącza art. $358^{1} \S 4$ k.c. w odniesieniu do strony prowadzącej przedsiębiorstwo, jeżeli świadczenie jest związane z prowadzeniem tego przedsiębiorstwa ${ }^{35}$. W uchwale Sąd Najwyższy stwierdził, że świadczenie pieniężne należne spółdzielczemu przedsiębiorstwu od spółdzielni mieszkaniowej z tytułu udziału w kosztach inwestycji tej spółdzielni nie pozostaje w związku z prowadzeniem przedsiębiorstwa. Może się domagać jego waloryzacji uznając, że w art. $358^{1} \S 4$ k.c. chodzi o przedsiębiorstwo w znaczeniu art. $55^{1}$ k.c. Sąd Najwyższy zwrócił uwagę na ważny element jego definicji, jakim jest cel w postaci realizacji zadań gospodarczych, którego synonimem jest prowadzenie działalności gospodarczej. Następnie w dalszej części uzasadnienia zostały wyraźnie zaakcentowane wskazywane w orzecznictwie cechy działalności gospodarczej. Niewątpliwie cel działalności gospodarczej powinien być wykorzystywany przy określeniu zakresu prowadzenia przedsiębiorstwa. Natomiast umowa zawarta przez strony nie musi pozostawać $\mathrm{w}$ związku z prowadzoną działalnością gospodarczą ${ }^{36}$.

Odmienną koncepcję zaprezentował Sąd Najwyższy, w uzasadnieniu ${ }^{37}$ podkreślając, że w skład przedsiębiorstwa według art. $55^{1}$ k.c. wchodzą także zobowiązania związane z jego prowadzeniem, których nie wiąże się w nim z realizacją zadań gospodarczych, z prowadzeniem działalności gospodarczej, lecz z prowadzeniem przedsiębiorstwa. Pojęcie ,prowadzenie przedsiębiorstwa” jest terminem szerszym niż pojęcie „prowadzenie działalności gospodarczej”. Uzasadniony jest wniosek, iż zobowiązania jako jeden ze składników przedsiębiorstwa obejmują

${ }^{32}$ Zob. art. $109^{1} \S 1$, art. $358^{1} \S 4$, art. 554, art. $583 \S 1$, art. 751 pkt 1 k.c.

33 P. Bielski, Glosa do wyroku Sądu Najwyższego z 14 stycznia 2004 r. ..., s. 57.

34 Ibidem, s. 58.

35 J.P. Naworski, op. cit.

36 Zob. uchwała Sądu Najwyższego z 17 marca 1993 r. sygn. akt III CZP 30/93, OSNC 1993/9, poz. 154 .

37 Zob. wyrok Sądu Najwyższego z 27 stycznia 1995 r., sygn. akt I CRN 179/94, OSNC 1995/6, poz. 99. 
zarówno te wynikające $\mathrm{z}$ działalności gospodarczej, jak i zobowiązania z nią tylko związane. Świadczenie z art. $358^{1} \S 4$ k.c. pozostające w związku z prowadzeniem przedsiębiorstwa jest tożsame $\mathrm{z}$ wymienionym $\mathrm{w}$ art. $55^{1}$ k.c. zobowiązaniem związanym z prowadzeniem przedsiębiorstwa. W związku z brakiem zastrzeżeń nie ma podstaw do upatrywania innego znaczenia pojęcia świadczenia pozostającego $\mathrm{w}$ związku z prowadzeniem przedsiębiorstwa użytego w art. $358^{1} \S 4$ k.c. niż to, w jakim zostało ono użyte w art. $55^{1}$ k.c. W konsekwencji Sąd Najwyższy uznał, że powód jest podmiotem prowadzącym przedsiębiorstwo, a poniesione przez niego nakłady na lokal handlowy, z którego korzysta, pozostawały w związ$\mathrm{ku} z$ prowadzeniem przedsiębiorstwa. W rezultacie nie przysługuje mu prawo żądania waloryzacji świadczenia pieniężnego. Wyrok Sądu Najwyższego z dnia 7 lipca 1997 r. prezentuje podobne stanowisko, w którym dokonano analizy dwóch opisanych uprzednio orzeczeń. Zgodnie z tym wyrokiem dyspozycją art. $358^{1} \S 4$ k.c. są objęte także świadczenia pieniężne należne podmiotowi gospodarczemu prowadzącemu przedsiębiorstwo w rozumieniu art. $55^{1}$ k.c. $\mathrm{z}$ tytułu finansowania inwestycji jako bazy lokalowej do prowadzenia podstawowej dla tego podmiotu działalności handlowej lub usługowej ${ }^{38}$. Przedstawione uzasadnienie Sądu Najwyższego prezentuje element wyjściowy dotyczący pojmowania określenia strony prowadzącej przedsiębiorstwo, jaki powinien zostać zachowany w celu prawidłowej interpretacji przepisów zawartych w art. $3581 \S 4$ k.c. Stanowi ono odwołanie do art. $55^{1}$ k.c., który zawiera przedmiotową definicję przedsiębiorstwa. Dla wykładni art. $358^{1} \S 4$ k.c. oznacza, że zwrot ,strona prowadząca przedsiębiorstwo" należy rozumieć jako podmiot gospodarczy (osoba fizyczna, osoba prawna) prowadzący przedsiębiorstwo w rozumieniu art. $55^{1}$ k.c. Założenie to Sąd Najwyższy uznał za bezsporne. Analizując treść art. $358^{1} \S 4$ i art. $55^{1}$ k.c., stwierdził, że sformułowanie ,jeżeli świadczenie pozostaje w związku z prowadzeniem przedsiębiorstwa" oznacza wyłączenie spod klauzuli art. $358^{1} \S 4$ k.c. świadczeń niepozostających w związku z prowadzeniem przedsiębiorstwa. Zgodnie z art. $55^{1}$ k.c. jednym ze składników niematerialnych przedsiębiorstwa, przeznaczonych do realizacji zadań gospodarczych, są zobowiązania i obciążenia związane z prowadzeniem przedsiębiorstwa ${ }^{39}$.

Bezsporne jest, że w art. $358^{1} \S 4$ k.c. chodzi o świadczenia należne stronie prowadzącej przedsiębiorstwo, czyli wierzytelność. Można zatem mówić o wierzytelnościach związanych z prowadzeniem przedsiębiorstwa, przy czym w kontekście art. $55^{1}$ k.c. wierzytelności te przeznaczone są do realizacji określonych działań gospodarczych. Według Sądu Najwyższego nie sposób podzielić pogląd wyrażony w uzasadnieniu wyroku z 27 stycznia 1995 r., iż w art. $55^{1}$ pkt 5 k.c. zobowiązań i obciążeń nie wiąże się z realizacją zadań gospodarczych. Jeśli przyjmie się, że dla wykładni art. $358^{1} \S 4$ k.c. istotne znaczenie ma definicja przedsię-

38 J.P. Naworski, op. cit.

39 Zob. wyrok Sądu Najwyższego z 7 stycznia 1997 r., sygn. akt I CKN 33/96, OSNC 1997/5, poz. 56. 
biorstwa od strony przedmiotowej, zawarta w art. $55^{1}$ k.c., to wówczas zgodnie $\mathrm{z}$ tą definicją w skład przedsiębiorstwa wchodzą m.in. składniki niematerialne przeznaczone do realizacji określonych zadań gospodarczych. Takie świadczenia, jak wierzytelności, wchodzą zatem w skład przedsiębiorstwa. Są to składniki niematerialne przeznaczone do realizacji określonych zadań gospodarczych. Wówczas zaprzeczeniem tego byłoby stanowisko, że nie pozostają one w związku $\mathrm{z}$ art. $358^{1} \S 4$ k.c. $w$ rozumieniu prowadzenia przedsiębiorstwa ${ }^{40}$.

\section{INSTYTUCJA PRZEDAWNIENIA ROSZCZEŃ PRZEDSIĘBIORCÓW}

Niewątpliwie należy też podjąć kwestię dotyczącą wykładni przepisów związanych z regulowaniem przedawnienia roszczeń przedsiębiorców. Podstawowy $\mathrm{w}$ tej materii art. 118 k.c., stanowiący lex generalis, ustala in fine trzyletni termin przedawnienia roszczeń związanych z prowadzeniem działalności gospodarczej. Lex specialis art. 554 in principio i art. 751 pkt 1 k.c. przewidują dwuletni termin przedawnienia: pierwszy — roszczeń z tytułu sprzedaży dokonanej w zakresie działalności przedsiębiorstwa sprzedawcy; drugi — roszczeń o wynagrodzenie za spełnione czynności i o zwrot poniesionych wydatków, przysługujące osobom, które w zakresie działalności przedsiębiorstwa trudnią się czynnościami danego

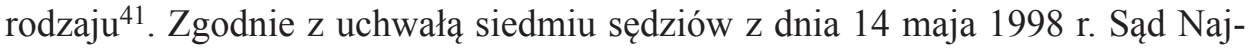
wyższy wskazał, że należy dostrzegać różnicę pomiędzy zakresem pojęć „,prowadzenie działalności gospodarczej” a „prowadzeniem przedsiębiorstwa”. Podstawą działalności gospodarczej jest aktywność przedsiębiorcy. Czynności podejmowane przez ten podmiot wchodzą w zakres jego działalności gospodarczej, gdy pozostają w normalnym, funkcjonalnym związku z tą działalnością. W szczególności są podejmowane $\mathrm{w}$ celu realizacji zadań związanych z przedmiotem działalności tego podmiotu. Należy zwrócić uwagę na szersze co do zakresu pojęcia „prowadzenie przedsiębiorstwa” oraz „czynności pozostające w związku z prowadzeniem przedsiębiorstwa”. W obrębie tych pojęć znajdą się m.in. czynności związane $\mathrm{z}$ funkcjonowaniem przedsiębiorstwa $\mathrm{w}$ znaczeniu przedmiotowym. $\mathrm{W}$ takim kontekście z prowadzeniem przedsiębiorstwa może ewentualnie pozostawać wykonywanie zadania polegającego na utrzymywaniu w stanie gotowości bezczynnych linii produkcyjnych. Tego rodzaju czynności nie pozostają bowiem w związku z działalnością gospodarczą. Nie polegają na uczestnictwie w obrocie gospodarczym. Nie prowadzą do wytwarzania dóbr materialnych. Nie przynoszą żadnego zysku. W rezultacie w rozumieniu art. 118 k.c. nie wykazują zatem cech działań pozostających w związku z prowadzeniem działalności gospodarczej².

40 J.P. Naworski, op. cit.

41 Ibidem.

42 Zob. uchwała składu siedmiu sędziów Sądu Najwyższego z 14 maja 1998 r., sygn. akt III CZP 12/98, OSNC 1998/10, poz. 151. 
Podobne stanowisko zajął Sąd Apelacyjny w Katowicach w uzasadnieniu wyroku z dnia 20 grudnia 2002 r. stwierdzając, że roszczenie regresowe na podstawie art. $441 \S 2$ k.c. nie pozostaje w normalnym, funkcjonalnym związku z działalnością gospodarczą spółki węglowej, a tym bardziej dochodzenie tego roszczenia nie ma na celu realizacji zadań związanych z wydobywaniem węgla kamiennego. Bez wątpienia stanowi to czynność związaną przedmiotowo z funkcjonowaniem przedsiębiorstwa, a żądanie regresowe, o którym mowa, nie jest roszczeniem związanym z prowadzeniem działalności gospodarczej - ulega więc przedawnieniu po upływie dziesięciu lat ${ }^{43}$. W tym nurcie mieści się też wyrok z dnia 14 listopada 2013 r., w którym Sąd Najwyższy uznał, że nabycie przez przedsiębiorcę udziałów w spółce z ograniczoną odpowiedzialnością należy uznać za związane z prowadzeniem przedsiębiorstwa, a nie działalności gospodarczej, a roszczenie $\mathrm{z}$ tego tytułu dochodzone na podstawie art. $410 \S 2$ k.c. za przedawniające się z upływem lat dziesięciu ${ }^{44}$. Odmienny pogląd wyraził Sąd Najwyższy w wyroku z dnia 14 stycznia 2004 r. W jego uzasadnieniu podkreślił, że wprowadzając do kodeksu cywilnego przepis art. $55^{1}$ zawierający definicję przedsiębiorstwa $\mathrm{w}$ znaczeniu przedmiotowym, ustawodawca zaaprobował rozróżnienie podmiotów obrotu profesjonalnego na podmioty prowadzące działalność gospodarczą oraz na prowadzące ją w formie przedsiębiorstwa. Konsekwencją było stwierdzenie, że przewidziany w art. 751 pkt 1 k.c. dwuletni termin przedawnienia dotyczy roszczeń o wynagrodzenie za czynności spełnione przez osobę prowadzącą przedsiębiorstwo w rozumieniu art. $55^{1}$ k.c. Należy mieć na uwadze, że nie może być stosowany do wszystkich podmiotów prowadzących działalność gospodarczą ${ }^{45}$. Tożsamej wykładni w zakresie działalności przedsiębiorstwa użytej w art. 554 in principio k.c. dokonał Sąd Najwyższy w uchwale z dnia 29 lutego 1996 r. Jej wynikiem było uznanie, że przewidziany w tym przepisie dwuletni termin przedawnienia nie może być stosowany do wszystkich prowadzących działalność gospodarczą tego rodzaju, lecz jedynie do tych spośród nich, którzy prowadzą przedsiębiorstwo w znaczeniu przedmiotowym ${ }^{46}$. Natomiast w wyroku z dnia 6 czerwca 2012 r. Sądu Najwyższego odnajdziemy jeszcze inne podejście do prowadzenia przedsiębiorstwa i prowadzenia działalności gospodarczej. Sąd Najwyższy wprawdzie przeciwstawiał sobie prowadzenie przedsiębiorstwa i prowadzenie działalności gospodarczej, uznając to pierwsze za pojęcie szersze. Nie nadał jednak temu żadnego znaczenia - dokonał analizy jedynie z uwagi na zarzut przedawnienia, czy

43 Zob. wyrok Sądu Apelacyjnego w Katowicach z 20 grudnia 2002 r., sygn. akt I ACa 701/02, OSA 2003/9, poz. 39.

44 P. Bielski, Glosa do wyroku Sądu Najwyższego z 14 listopada 2013 r., sygn. akt II CSK 104/13, LEX el. 2014.

45 Zob. wyrok Sądu Najwyższego z 14 stycznia 2004 r., sygn. akt I CK 54/03, OSNC 2005/2, poz. 35 .

46 Zob. uchwała Sądu Najwyższego z 29 lutego 1996 r., sygn. akt III CZP 13/96, OSNC 1996/5, poz. 71 . 
in concreto dochodzone roszczenie oparte na konstrukcji nienależnego świadczenia było czy nie było związane z prowadzeniem działalności gospodarczej" ${ }^{47}$. W uchwale z dnia 16 września 2010 r., w której chodziło o roszczenie przedsiębiorcy będącego spółką z ograniczoną odpowiedzialnością o wynagrodzenie za bezumowne korzystanie z jego nieruchomości, jak i o termin przedawnienia tego roszczenia, nie ma już w ogóle mowy o podziale działań podejmowanych przez przedsiębiorcę na te mające związek z prowadzeniem przedsiębiorstwa, ale nie z prowadzeniem przez niego działalności gospodarczej ${ }^{48}$. Sąd Najwyższy, przyjmując, że dochodzone $\mathrm{w}$ sprawie roszczenia przedawnia się $\mathrm{w}$ terminie trzech lat, nawiązał do definicji przedsiębiorcy zawartej w art. $43^{1}$ k.c. Stwierdził, iż skoro czynności dokonuje przedsiębiorca, to przemawia za tym domniemanie, że wchodzi ona w zakres działalności gospodarczej. Należy zatem założyć, że jeżeli $\mathrm{z}$ roszczeniem występuje przedsiębiorca, to jest to roszczenie związane z prowadzoną przez niego działalnością gospodarczą ${ }^{49}$. Tylko gdyby dokonanie czynności lub dochodzenie roszczenia nie pozostawało w żadnym funkcjonalnym związku z przedmiotem prowadzonej przez przedsiębiorcę działalności, należałoby uznać, że nie jest to czynnością o charakterze gospodarczym. O pozostawaniu czynności lub roszczenia w funkcjonalnym związku z prowadzeniem działalności gospodarczej nie decyduje stałość, typowość określonych czynności lub roszczenia ani to, czy należą one do zakresu podstawowej działalności przedsiębiorcy ${ }^{50}$.

\section{PODSUMOWANIE}

Reasumując powyższe rozważania, możemy stwierdzić, że dopiero tzw. czynnik organizacyjny zespalający składniki niematerialne i materialne w jedną funkcjonalną całość pozwala je uznać za przedsiębiorstwo. Dzięki niemu przedsiębiorstwo nabiera charakteru organicznego. W pewien sposób alienuje się od osoby przedsiębiorcy, a nawet od swojego substratu materialnego, który może mieć charakter dynamiczny lub zmienny w czasie. Przedsiębiorstwo jako samodzielny twór tak dalece oddziela się od osoby przedsiębiorcy, że nabywa zdolność do samodzielnego funkcjonowania $\mathrm{w}$ obrocie ${ }^{51}$. Świadczyć o tym może również swoista dychotomia, która zarysowuje się, gdy przedsiębiorstwo jest prowadzone

47 Zob. wyrok Sądu Najwyższego z 6 czerwca 2012 r., sygn. akt III CSK 282/11, LEX nr 1212813.

48 Zob. uchwała Sądu Najwyższego z 16 września 2010 r., sygn. akt III CZP 44/10, OSNC-ZD 2011/A, poz. 19.

49 P. Bielski, Glosa do uchwaty Sądu Najwyższego z 16 września 2010 r., sygn. akt III CZP 44/10, ,Glosa” 2012, nr 1, s. 58-68.

50 J.P. Naworski, op. cit.

51 M. Poźniak-Niedzielska, Dobra niematerialne przedsiębiorstwa państwowego, Warszawa-Łódź 1990, s. 26. 
przez użytkownika lub dzierżawcę a kto inny jest wówczas właścicielem składników trwałych i stroną umów długoterminowych związanych z funkcjonowaniem przedsiębiorstwa, a kto inny dokonuje czynności prawnych w ramach jego bieżącej działalności. lecz nie narusza to jednak integralności przedsiębiorstwa ${ }^{52}$. Występowanie elementu organizacji oraz funkcjonalnego powiązania różnorodnych jego składników umożliwiających traktowanie przedsiębiorstwa jako pewnej całości ${ }^{53}$ jest czynnikiem konstytuującym przedsiębiorstwo w znaczeniu przedmiotowym ${ }^{54}$. Wątpliwości budzi zagadnienie, czy każdy składnik przedsiębiorstwa musi być bezpośrednio związany z prowadzoną za pomocą przedsiębiorstwa działalnością gospodarczą i realizacją zadań gospodarczych. Sąd Najwyższy w postanowieniu ${ }^{55}$ przyjął, że nieruchomości wykorzystywane na cele rekreacyjno-wypoczynkowe załogi nie wchodzą w skład przedsiębiorstwa. Warunkiem uznania za składnik przedsiębiorstwa powinno być ustalenie związku między jego cechami a realizacją zadań gospodarczych ${ }^{56}$.

Przedsiębiorstwo jest przeznaczone do prowadzenia działalności gospodarczej, a pojęcie działalności gospodarczej zostało de lege lata zdefiniowane przez ustawodawcę w art. 2 ustawy o swobodzie działalności gospodarczej. Zgodnie z tym przepisem działalnością gospodarczą jest zarobkowa działalność wytwórcza, budowlana, handlowa, usługowa oraz poszukiwanie, rozpoznawanie i wydobywanie kopalin ze złóż, a także działalność zawodowa, wykonywana w sposób zorganizowany i ciągły. Wątpliwości w doktrynie budzi m.in. zagadnienie stosunku pojęć działalności gospodarczej i działalności zawodowej ${ }^{57}$.

Teza o możliwości prowadzenia przez przedsiębiorcę więcej niż jednego przedsiębiorstwa $\mathrm{w}$ znaczeniu przedmiotowym znajduje też potwierdzenie w orzecznictwie ${ }^{58}$. Konsekwencją traktowania przedsiębiorstwa jako samoistnego dobra prawnego jest twierdzenie, że przedsiębiorstwo stanowi przedmiot majątkowego prawa podmiotowego oraz że istnieje prawo podmiotowe oparte na przedsiębiorstwie ${ }^{59}$. Wskazuje się, że stanowi ono prawo o charakterze bezwzględnym, a zastosowanie do niego znajdowałyby reguły prawa rzeczowego. Niektórzy autorzy uznają w związku z tym, że przedsiębiorstwo jest przedmiotem prawa wła-

52 R. Morek, komentarz do art. $55^{1}$ k.c.

53 Zob. wyrok Sądu Najwyższego z 3 grudnia 2009 r., sygn. akt II CSK 215/09.

54 Zob. wyrok Sądu Najwyższego z 25 listopada 2010 r., sygn. akt I CSK 703/09.

55 Zob. postanowienie Sądu Najwyższego z dnia 29 września 2000 r., sygn. akt V CKN 92/00.

56 P. Bielski, Glosa do uchwaty Sądu Najwyższego z 13 grudnia 2000 r., sygn. akt III CZP 43/00 oraz Glosa do uchwały Sądu Najwyższego z 12 stycznia 2001 r., sygn. akt III CZP 44/00, PPH 2001, nr 6, s. 46.

57 A. Wiśniewski, Stan prywatnego prawa gospodarczego a optymalna wizja kodeksu cywilnego - zagadnienia podmiotowe, PPH 2008, nr 6, dodatek, s. 8.

58 Zob. uchwała Sądu Najwyższego z 12 stycznia 2001 r., sygn. akt III CZP 44/00, OSNC 2001, nr 5, poz. 69 oraz postanowienie Sądu Najwyższego z 9 grudnia 2010 r., sygn. akt IV CSK 210/10.

59 W. Katner, op. cit., Nb 152. 
sności lub ewentualnie prawa podobnego do własności. Wówczas prawo to bywa też nazywane prawem własności na przedsiębiorstwie ${ }^{60}$. Przyjmuje się na ogół, że art. $55^{1}$ k.c. zawiera definicję przedsiębiorstwa $\mathrm{w}$ znaczeniu przedmiotowym i ze względu jednak na to, że wkomponowany w nią został czynnik organizacyjny, definicji tej przypisuje się znaczenie przedmiotowo-funkcjonalne ${ }^{61}$. W znaczeniu podmiotowym pojęcie przedsiębiorstwa bywa używane do oznaczenia podmiotu, który prowadzi działalność gospodarczą. Identyfikuje ono wówczas podmiot, dzięki któremu przedsiębiorstwo w znaczeniu przedmiotowym uczestniczy w obrocie gospodarczym i prawnym. Najczęściej wskazywanym przykładem takiego zastosowania pojęcia przedsiębiorstwa jest przedsiębiorstwo państwowe, mimo iż pojęcie podmiotowe przedsiębiorstwa bywa obecnie utożsamiane z przedsiębiorcą $^{62}$. W doktrynie postawiono pytanie o minimum składników, których obecność jest konieczna, by mówić o przedsiębiorstwie. Zdaniem Z. Gawlika literalna wykładnia art. $55^{1}$ k.c. prowadzi do wniosku, że zorganizowany zespół, w skład którego wchodzi co najmniej jeden składnik niematerialny i co najmniej jeden materialny, nosi znamiona wymagane do uznania go za przedsiębiorstwo ${ }^{63}$. W skład przedsiębiorstwa wchodzą także prawa własności nieruchomości lub ruchomości, do których zaliczyć trzeba przede wszystkim prawa do rozmaitych urządzeń, sprzętów, materiałów, wyrobów, towarów, surowców, środków wytwórczych, pojazdów. Oprócz praw własności do podobnych rzeczy w skład przedsiębiorstwa mogą też wchodzić prawa rzeczowe na tych rzeczach, w tym wieczyste użytkowanie nieruchomości, użytkowanie lub służebności.

\section{ENTERPRISE IN THE POLISH LEGAL SYSTEM}

\section{Summary}

The presented study is a presentation of the problem of the concept of enterprise in the Polish legal system. The purpose of this paper is to present the complexity of the definition of an enterprise in the light of applicable legal provisions, judicial decisions and legal dogmatics.

Due to the nature of the article, the main research method will be an objective analysis of the legal order regulating the enterprise's issues aimed at systematizing the most important issues in the presented topic.

Keywords: enterprise, legal system, economic activity, enterprise components

${ }^{60}$ E. Gniewek, [w:] Kodeks cywilny. Komentarz, wyd. 4, red. E. Gniewek, Warszawa 2014, s. $110-132$.

61 R. Stroiński, Przedsiębiorstwo, charakter prawny oraz zbycie w prawie amerykańskim, francuskim i polskim, Warszawa 2002, s. 305.

62 W. Katner, op. cit.

63 Z. Gawlik, op. cit., s. 277. 


\section{BIBLIOGRAFIA}

\section{LITERATURA}

Gawlik Z., [w:] Kodeks cywilny. Komentarz, t. 1, Część ogólna, red. A. Kidyba, Warszawa 2009, s. $275-278$.

Gniewek E., [w:] Kodeks cywilny. Komentarz, wyd. 4, red. E. Gniewek, Warszawa 2014, s. 110-132.

Katner W.J., [w:] Prawo cywilne - część ogólna, System Prawa Prywatnego, t. 1, wyd. 1, red. M. Safjan, Warszawa 2007, s. 1216-1224.

Pazdan M., [w:] Kodeks cywilny. Komentarz, t. 1, red. K. Pietrzykowski, Warszawa 2004.

Pazdan M., [w:] System prawa prywatnego, t. 2, Prawo cywilne - część ogólna. Suplement, red. Z. Radwański, Warszawa 2004, s. 90-103.

Poźniak-Niedzielska M., Dobra niematerialne przedsiębiorstwa państwowego, Warszawa-Łódź 1990, s. 26.

Sołtysiński S., [w:] Kodeks spółek handlowych, t. 1, Przepisy ogólne. Spółki osobowe. Komentarz do art. 1-150, red. S. Sołtysiński, A. Szajkowski, A. Szumański, J. Szwaja, Warszawa 2012, s. $376-446$.

Stroiński R., Przedsiębiorstwo, charakter prawny oraz zbycie w prawie amerykańskim, francuskim i polskim, Warszawa 2002, s. 281-305.

Strzępka J.A., Zielińska E., [w:] Kodeks spółek handlowych. Komentarz, red. J.A. Strzępka, Warszawa 2009, s. 3-51.

Sychowicz M., [w:] Komentarz do kodeksu cywilnego. Księga trzecia. Zobowiazania, t. 2, red. G. Bieniek, Warszawa 1997.

Szwaja J., [w:] Kodeks spótek handlowych. Komentarz, t. 5, red. S. Sołtysiński, A. Szajkowski, A. Szumański, Warszawa 2004.

Szwaja J., Nowy kodeks spótek handlowych. Cz. 1, „Prawo Spółek” 2001, nr 1, s. 7-11.

Szwaja J., Mika I.B., [w:] Kodeks spółek handlowych, t. 1, Przepisy ogólne. Spótki osobowe. Komentarz do art. 1-150, red. S. Sołtysiński, A. Szajkowski, A. Szumański, J. Szwaja, Warszawa 2012.

Wiśniewski T., [w:] Komentarz do kodeksu cywilnego. Księga trzecia. Zobowiązania, t. 1, red. G. Bieniek, Warszawa 1996, s. 1-23.

\section{ORZECZNICTWO}

Postanowienie Sądu Najwyższego — Izba Cywilna z dnia 9 grudnia 2010 r., sygn. akt IV CSK 210/10, publikacja Legalis nr 414631.

Postanowienie Sądu Najwyższego z dnia 29 września 2000 r., sygn. akt V CKN 92/00.

Uchwała Sądu Najwyższego z 17 marca 1993 r., sygn. akt III CZP 30/93, OSNC 1993/9, poz. 154.

Uchwała Sądu Najwyższego z 29 lutego 1996 r., sygn. akt III CZP 13/96, OSNC 1996/5, poz. 71.

Uchwała Sądu Najwyższego z 12 stycznia 2001 r., sygn. akt III CZP 44/00, OSNC 2001, Nr 5, poz. 69.

Uchwała Sądu Najwyższego z 16 września 2010 r., sygn. akt III CZP 44/10, OSNC-ZD 2011/A, poz. 19.

Uchwała składu siedmiu sędziów Sądu Najwyższego z 14 maja 1998 r., sygn. akt III CZP 12/98, OSNC 1998/10.

Wyrok Sądu Apelacyjnego w Katowicach z 20 grudnia 2002 r., sygn. akt I ACa 701/02, OSA 2003/9, poz. 39.

Wyrok Sądu Najwyższego z 27 stycznia 1995 r., sygn. akt I CRN 179/94, OSNC 1995/6, poz. 99.

Wyrok Sądu Najwyższego z 7 stycznia 1997 r., sygn. akt I CKN 33/96, OSNC 1997/5, poz. 56.

Wyrok Sądu Najwyższego z 14 stycznia 2004 r., sygn. akt I CK 54/03, OSNC 2005/2, poz. 35.

Wyrok Sądu Najwyższego z 3 grudnia 2009 r., sygn. akt II CSK 215/09. 
Wyrok Sądu Najwyższego z 25 listopada 2010 r., sygn. akt I CSK 703/09.

Wyrok Sądu Najwyższego z 6 czerwca 2012 r., sygn. akt III CSK 282/11, LEX nr 1212813.

\section{PERIODYKI}

Bielski P., Cele definiowania gospodarstwa rolnego w systemie prawa - uwagi z perspektywy prawa handlowego, ,Rejent” 2005, nr 9, s. 62-74.

Bielski P., Glosa do uchwały Sądu Najwyższego z 13 grudnia 2000 r., sygn. akt III CZP 43/00, PPH 2001, nr 6, s. 43-51.

Bielski P., Glosa do uchwały Sądu Najwyższego z 12 stycznia 2001 r., sygn. akt III CZP 44/00, PPH 2001, nr 6, s. 43-51.

Bielski P., Glosa do uchwaty Sądu Najwyższego z 16 września 2010 r., sygn. akt III CZP 44/10, „Glosa” 2012, nr 1, s. 58-68.

Bielski P., Glosa do wyroku Sądu Najwyższego z 17 października 2000 r., I CKN 850/98, PPH 2004, nr 3, s. 46-51.

Bielski P., Glosa do wyroku Sadu Najwyższego z 14 stycznia 2004 r., sygn. akt I CK 54/03, „Prawo Spółek" 2007, nr 5.

Bielski P., Glosa do wyroku Sądu Najwyższego z 14 listopada 2013 r., sygn. akt II CSK 104/13, LEX el. 2014.

Bielski P., Spółka partnerska - spótka handlowa??, „Prawo Spółek” 2006, nr 2, s. 12-19.

Buczkowski S., Glosa do wyroku Sąu Najwyższego z 10 stycznia 1972 r., OSPiKA 1972, nr 12.

Naworski J.P., Przedsiębiorca i przedsiębiorstwo w polskim prawie prywatnym, cz. I, „Przegląd Prawa Handlowego" 2015, nr 8, s. 4-12.

Pazdan M., Kodeks spótek handlowych a kodeks cywilny, „Państwo i Prawo” 2001, nr 2, s. 28-36.

Wiśniewski A., Stan prywatnego prawa gospodarczego a optymalna wizja kodeksu cywilnego zagadnienia podmiotowe, PPH 2008, nr 6, dodatek, s. 1-23. 